\title{
Impact of plant extracts tested in attention- deficit/hyperactivity disorder treatment on cell survival and energy metabolism in human neuroblastoma SH-SY5Y cells
}

\begin{tabular}{|r|l|}
\hline Journal: & Phytotherapy Research \\
\hline Manuscript ID: & PTR-09-0998.R2 \\
\hline Wiley - Manuscript type: & Full Paper \\
\hline Date Submitted by the & 23-Mar-2010 \\
\hline Complete List of Authors: & $\begin{array}{l}\text { Schmidt, Andreas; Philipps-University Marburg, Department of } \\
\text { Psychiatry and Psychotherapy } \\
\text { Krieg, Jürgen-Christian; Philipps-University Marburg, Department of } \\
\text { Psychiatry and Psychotherapy } \\
\text { Hemmeter, Ulrich; Philipps-University Marburg, Department of } \\
\text { Psychiatry and Psychotherapy } \\
\text { Kircher, Tilo; University of Marburg, Dept. of Psychiatry } \\
\text { Schulz, Eberhard; Albert-Ludwigs-University Freiburg, Department } \\
\text { of Child and Adolescent Psychiatry } \\
\text { Clement, Hans-Will; Albert-Ludwigs-University Freiburg, } \\
\text { Department of Child and Adolescent Psychiatry } \\
\text { Heiser, Philip; Albert-Ludwigs-University Freiburg, Department of } \\
\text { Child and Adolescent Psychiatry }\end{array}$ \\
\hline Keyword: & $\begin{array}{l}\text { Pycnogenol, Enzogenol, Hypericum, cell survival, energy } \\
\text { metabolism, neuroblastoma cells }\end{array}$ \\
\hline \hline
\end{tabular}

\section{S ScholaroNE \\ Manuscript Central}




\section{Impact of plant extracts tested in attention-deficit/hyperactivity disorder}

\section{treatment on cell survival and energy metabolism}

\section{in human neuroblastoma SH-SY5Y cells}

Andreas Johannes Schmidt ${ }^{\mathrm{a}}$, Jürgen-Christian Krieg ${ }^{\mathrm{a}}$, Ulrich Michael Hemmeter ${ }^{\mathrm{a}}$, Tilo

Kircher $^{\mathrm{a}}$, Eberhard Schulz ${ }^{\mathrm{b}}$, Hans-Willi Clement ${ }^{\mathrm{b}}$, Philip Heiser ${ }^{\mathrm{b}}{ }^{*}$

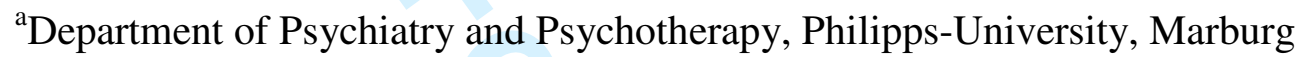

${ }^{\mathrm{b}}$ Department of Child and Adolescent Psychiatry, Albert-Ludwigs-University, Freiburg

Correspondence and proofs to: $\quad$ Prof. Dr. med. Philip Heiser

Department of Child and Adolescent Psychiatry

Albert-Ludwigs-University

Hauptstrasse 8

D-79104 Freiburg, Germany

Tel.: $\quad+497612706606$

Fax.: $\quad+497612706949$ 


\begin{abstract}
Plant extracts like Hypericum perforatum and Pycnogenol ${ }^{\circledR}$ have been tested as alternatives to the classical ADHD drugs. It has been possible to describe neuroprotective effects of such plant extracts. A reduction of ADHD symptoms could be shown in clinical studies after the application of Pycnogenol ${ }^{\circledR}$, which is a pine bark extract. The impacts of the standardized herbal extracts Hypericum perforatum, Pycnogenol ${ }^{\circledR}$ and Enzogenol ${ }^{\circledR}$ up to a concentration of $5.000 \mathrm{ng} / \mathrm{ml}$ on cell survival and energy metabolism in human SH-SY5Y neuroblastoma cells has been investigated in the present examination. Hypericum perforatum significantly decreased survival of cells after treatment with a concentration of $5000 \mathrm{ng} / \mathrm{ml}$, whereas lower concentrations exerted no significant effects. Pycnogenol ${ }^{\circledR}$ induced a significant increase of cell survival after incubation with a concentration of $32.25 \mathrm{ng} / \mathrm{ml}$ and a concentration of $250 \mathrm{ng} / \mathrm{ml}$. Other applied concentrations of Pycnogenol ${ }^{\circledR}$ failed to exert significant effects. Treatment with Enzogenol ${ }^{\circledR}$ did not lead to significant changes in cell survival.
\end{abstract}

Concerning energy metabolism, treatment of cells with a concentration of $5000 \mathrm{ng} / \mathrm{ml}$ Hypericum perforatum led to a significant increase of ATP levels, whereas treatment with a concentration of $500 \mathrm{ng} / \mathrm{ml}$ had no significant effect. Incubation of cells with Pycnogenol ${ }^{\circledR}$ and Enzogenol ${ }^{\circledR}$ exerted no significant effects.

None of the tested substances caused any cytotoxic effect when used in therapeutically-relevant concentrations.

Keywords: Pycnogenol ${ }^{\circledR}$, Enzogenol $^{\circledR}$, Hypericum, cell survival, energy metabolism, neuroblastoma cells 


\section{Introduction}

Over decades, the standard pharmacotherapy of attention-deficit/hyperactivity disorder (ADHD) had comprised psychostimulants like methylphenidate and amphetamine as well as the selective norepinephrine reuptake inhibitor atomoxetine later on. Since some patients do not respond to the classical ADHD drugs or show side effects, the use of herbal extracts like Hypericum perforatum or Pycnogenol $^{\circledR}$ (Pinus pinaster) as supplementation or as monotherapy has been discussed in the last few years. Concerning combinations of extracts, the results of a study by Lyon et al. (2001) suggest a possible improvement of ADHD symptoms after a supplementation with an extract combination of Panax quinquefolium and Ginkgo biloba.

The extract of Hypericum perforatum is known to exert both antioxidative properties and protective effects (e.g. Benedi et al., 2004; Breyer at al., 2007; El-Sherbiny et al., 2003; Sanchez-Reus et al., 2007). However, no improvement of ADHD symptoms after a treatment of eight weeks has been found in a recently published randomised, double-blind, placebocontrolled study (Weber et al., 2008). The patients had not received any other drugs during this study.

A plant extract which has been discussed extensively in terms of ADHD treatment over the last few years is Pycnogenol ${ }^{\circledR}$. Pycnogenol ${ }^{\circledR}$ stands for a bark extract of the French maritime pine (Pinus pinaster) and mainly consists of procyanidines as well as catechins and phenolic acids (Packer et al., 1999). The antioxidant activities of this extract have been described. It could be been shown in vitro that Pycnogenol® is a free radical scavenger (Packer et al., 1999), that it stimulates activities of antioxidant enzymes like $\mathrm{Cu}, \mathrm{Zn}$ superoxide dismutase (Fitzpatrick et al., 1998) and that it influences the glutathione metabolism (Berryman et al., 2004). Furthermore, protective effects of Pycnogenol ${ }^{\circledR}$ on neuronal cells in context with toxic insults like acrolein (Ansari et al., 2008), $\beta$-amyloid (Peng 
et al., 2002), ethanol (Siler-Marisiglio et al., 2004) or glutamate (Kobayashi et al., 2000) have been shown.

These characteristics of Pycnogenol ${ }^{\circledR}$ may be important factors for the treatment of ADHD, because indices for reactive oxygen species induced oxidative stress have been discussed in children and young adults, in part controversially (Antalis et al., 2006; Chovanova et al., 2006; Joshi et al., 2006; Ross, et al., 2003; Spahis et al., 2008) as well as in adults suffering from ADHD (Bulut et al., 2007; Selek et al., 2008).

Chovanova et al. (2006), measuring with comet essay, have found a significantly increased level of oxidative DNA damage in children with ADHD in comparison to healthy controls. Spahis et al. (2008) have described significantly reduced plasma malone dialdehyde levels in ADHD children, whereas Ross et al. (2003) have found significantly increased ethane levels in the alveolar breath of children with ADHD. Ethane is a non-invasive marker of oxidative damage to n-3 fatty acids. On the other hand, Joshi et al. (2006) have found no significant alterations of lipid peroxidation products in the plasma of children with ADHD compared to controls, while Antalis et al. (2006) have detected no significant differences of urinary isoprostanes comparing a young adult ADHD population with controls.

In order to investigate alterations of the antioxidant vitamin status in ADHD, Spahis et al. (2008) have measured the plasma levels of retinal, $\beta$-carotene and vitamin $\mathrm{E}$ in children with ADHD. The two vitamin E forms, $\alpha$ - and $\gamma$-tocopherol, have been found to be significantly higher in ADHD children compared with control subjects, whereas retionol and $\beta$-carotene contents showed no modifications.

Regarding adult patients, Bulut et al. (2007) have described significantly elevated malondialdehyde plasma levels, as a product of lipidperoxidation, which is induced by reactive oxygen species. In a recently published study, Selek et al. (2008) could show a significantly reduced activity of total $\mathrm{Cu}, \mathrm{Zn}$ superoxide dismutase as well as significantly enhanced levels of oxidant nitric oxide in the serum of adult patients with ADHD. 
Aiming at evaluating the effects of Pycnogenol ${ }^{\circledR}$ on ADHD symptoms, Trebaticka et al. (2006) could demonstrate in a randomised, placebo-controlled, double blind study, that a supplementation with Pycnogenol ${ }^{\circledR}$ for one month had caused a significant reduction of hyperactivity in children with ADHD, had improved attention and visual-motoric coordination and their ability to concentrate. One month after the treatment had finished, a relapse of symptoms had been observed. On the other hand, a study with adult patients had shown no reduction of ADHD symptoms after treatment with Pycnogenol ${ }^{\circledR}$ (Tenenbaum et al., 2002).

An extract similar to Pycnogenol ${ }^{\circledR}$ is Enzogenol ${ }^{\circledR}$, which is a bark extract of the New Zealand pine Pinus radiata containing flavonoids. In combination with vitamin C, Enzogenol ${ }^{\circledR}$ has improved the cognitive performance in older individuals (Pipingas et al., 2008). Vitamin C alone has failed to reach this effect. Previous studies (e. g. Young et al., 2006) which have been using this combination have indicated improvements of oxidative stress parameters.

Also Ginko biloba has been shown to be effective for treating ADHD however being less effective than methylphenidate (Niederhofer, 2010, Salehi et al., 2010).

Summarizing the studies cited above, only little is known about the effects of plant extracts on cell metabolism. Therefore, the aim of the present study was the examination of effects of both pine bark extracts and Hypericum perforatum on cell survival of human neuronal (SH-SY5Y) and on energy metabolism.

\section{Materials and Methods}

Preparation and incubation of cells

Human SH-SY5Y neuroblastoma cells were cultured in a $5 \% \mathrm{CO}_{2}$ atmosphere in heatinactivated Roswell Park Memorial Institute medium (RPMI) (Gibco/BRL, Eggenstein, Germany), supplemented with 15\% fetal calf serum (FCS) (Biochrom, Berlin, Germany), $1 \%$ penicillin-streptomycin and $1 \%$ glutamine. The Hypericum perforatum extract was a kind gift 
from Casella-med GmbH \& Co. KG (Köln, Germany). The pine bark extracts were obtained from the Department of Child and Adolescent Psychiatry at the Albert-Ludwigs-University of Freiburg. All drugs were dissolved in dimethylsulfoxide and concentrations of $31.25,62.5$, $125,250,625,1250,2500$ and $5000 \mathrm{ng} / \mathrm{ml}$ were applicated. A respective dissolvent was applied for controls. Each concentration was tested by a minimum of three single experiments.

\section{Measurement of metabolic activity and survival}

Cells were exposed to drugs in the above-mentioned concentrations for $24 \mathrm{~h}$ at a temperature of $37^{\circ} \mathrm{C}$, using 96-well dishes with 36,000 per well. The survival of cells was determined by a biochemical assay using a modified tetrazolium method (EZ4U, Biozol, Eching, Germany). This test is based on the ability of living cells to transform colourless tetrazolium salts into deeply coloured formazans by mitochondrial dehydrogenases. Cell viability was quantified by photometric determination of formazan-like products with an ELISA-reader (Dynex, Stuttgart, Germany).

\section{Measurement of ATP content}

36,000 cells per well were plated into 96-well dishes and exposed to the tested drugs in concentrations of 500 and $5000 \mathrm{ng} / \mathrm{ml}$ for $24 \mathrm{~h}$ at a temperature of $37^{\circ} \mathrm{C}$. The ATP content of cells was determined by using an ATP Bioluminescence Assay (Boehringer, Ingelheim, Germany).

The amount of ATP was measured by using a microplate scintillation counter "TopCount" (Perkin Elmer, Ueberlingen, Germany), which allows for quantitative measurement via luminescence which is detected by single photon counting. 


\section{Statistical analysis}

Data are expressed in a percentage of respective controls and are displayed as mean values \pm standard error of the mean (S.E.M.).

In order to evaluate the effects of treatment, Kruskal Wallis tests were used to determine differences among the treatment groups. In case of significance, Dunn's method was performed. The level of significance was set to $\mathrm{P}<0.05$. Statistical evaluation was carried out using SigmaStat software (Jandel Scientific, Erkrath, Germany).

\section{Results}

\section{Effects of plant extracts on survival of SH-SY5Y cells}

The impact of the plant extracts Hypericum perforatum, Pycnogenol ${ }^{\circledR}$ and Enzogenol ${ }^{\circledR}$ on cell survival was tested in human neuroblastoma SH-SY5Y cells in concentrations ranging from 31.25 to $5000 \mathrm{ng} / \mathrm{ml}$. The treatment of cells with Hypericum perforatum in concentrations of $5000 \mathrm{ng} / \mathrm{ml}(90 \pm 2 \%, \mathrm{p}<0.05)$ has significantly decreased the survival of cells (Fig.: 1). The treatment of cells with lower concentrations of Hypericum perforatum has exerted no significant effects (Fig.: 1). Pycnogenol ${ }^{\circledR}$ has induced a significant increase of cell survival after its incubation in concentrations of $32.25 \mathrm{ng} / \mathrm{ml}(112 \pm 2 \%, \mathrm{p}<0.05), 125$ $\mathrm{ng} / \mathrm{ml}(113 \pm 3 \%, \mathrm{p}<0.05)$ and $250 \mathrm{ng} / \mathrm{ml}(113 \pm 2 \%, \mathrm{p}<0.05)$, while concentrations of $62.5 \mathrm{ng} / \mathrm{ml}, 625 \mathrm{ng} / \mathrm{ml}(102 \pm 2 \%), 1250 \mathrm{ng} / \mathrm{ml}(104 \pm 2 \%), 2500 \mathrm{ng} / \mathrm{ml}(101 \pm 2 \%)$ and $5000 \mathrm{ng} / \mathrm{ml}(96 \pm 2 \%)$ have failed to exert significant effects (Fig.: 2). Treatment of SHSY5Y cells with Enzogenol ${ }^{\circledR}$ has not led to significant changes in cell survival (Fig.: 3).

\section{Effects of plant extracts on energy metabolism of SH-SY5Y cells}

The impact of plant extracts on the ATP content of human neuroblastoma cells was measured by using concentrations of 500 and $5000 \mathrm{ng} / \mathrm{ml}$. The incubation of cells with 
Pycnogenol $^{\circledR}(500 \mathrm{ng} / \mathrm{ml}: 98 \pm 6 \%, 5000$ ng/ml: $90 \pm 7 \%)$ and with Enzogenol ${ }^{\circledR}(500 \mathrm{ng} / \mathrm{ml}$ : $86 \pm 4 \%, 5000 \mathrm{ng} / \mathrm{ml}: 98 \pm 7 \%$ ) has exerted no significant effects (Fig.: 4 and 5), while the incubation with Hypericum perforatum in a concentration of $5000 \mathrm{ng} / \mathrm{ml}(135 \pm 9, \mathrm{p}<0.05)$ has resulted in a significant increase of ATP levels, whereas using a concentration of 500 ng/ml (106 $\pm 5 \%)$ had no significant impact (Fig.: 4 and 5).

\section{Discussion}

A group of substances for the treatment of ADHD which have been tested intensively over the last few years, are plant extracts with antioxidative or neuroprotective capacities like Pycnogenol $^{\circledR}$, Hypericum perforatum or Panax quinquefolium and Ginkgo biloba. Regarding these extracts, the focus of interest has been on Pycnogenol ${ }^{\circledR}$ in the last years. A chemically similar extract has been Enzogenol ${ }^{\circledR}$. The aim of the present study has laid on evaluating the effects of these plant extracts on both cell survival and energy metabolism of human neuroblastoma SH-SY5Y cells.

The neuroprotective impact of Hypericum perforatum (e.g. Breyer et al., 2007) and Pycnogenol $^{\circledR}$ (e. g. Peng et al., 2002) has been described in the literature. It has to be mentioned that in the course of our study, none of the tested substances have exerted any intense cytotoxic effect. In our study, treatment with Hypericum perforatum in a concentration of $5000 \mathrm{ng} / \mathrm{ml}$ has significantly decreased survival of cells, whereas using lower concentrations of Hypericum perforatum has exerted no significant effects. The incubation with Pycnogenol ${ }^{\circledR}$, using concentrations of $32.25 \mathrm{ng} / \mathrm{ml}$ and $250 \mathrm{ng} / \mathrm{ml}$ has induced a significant increase of cell survival, whereas the incubation with Enzogenol ${ }^{\circledR}$ has not led to any significant reactions at all. Both Benedi et al. (2004) and Breyer et al. (2007) have not found any significant effects of Hypericum perforatum on neuronal cell survival in comparable studies, whereas it has been shown that Pycnogenol ${ }^{\circledR}$ exerted protective effects against various neuronal cell insults. Ansari et al. (2008) have detected protective effects of 
Pycnogenol ${ }^{\circledR}$ following acrolein-induced cytotoxicity in SH-SY5Y cells. It could be shown that pre-treatment with Pycnogenol ${ }^{\circledR}$ in concentrations of 50 and $100 \mu \mathrm{g} / \mathrm{ml}$ ) has significantly reduced the amount of acrolein-induced reactive oxygen species, has reduced superoxide levels and reduced cell death. Furthermore, an attenuation of the decline of reduced glutathione has followed the preincubation of cells with Pycnogenol in concentrations of (50 and $100 \mu \mathrm{g} / \mathrm{ml}$ ), while a decrease of oxidized glutathione has followed the preincubation of cells with Pycnogenol ${ }^{\circledR}$ in a concentration of $50 \mu \mathrm{g} / \mathrm{ml}$. Pre-treatment with Pycnogenol ${ }^{\circledR}$ in concentrations of 50 and $100 \mu \mathrm{g} / \mathrm{ml}$ has also reduced the products of oxidative protein and membranlipid damage induced by acrolein significantly. The exclusive use of Pycnogenol ${ }^{\circledR}$ in concentrations of up to $200 \mu \mathrm{g} / \mathrm{ml}$ has had no effects on cells.

Peng et al. (2002) have examined the neuroprotective effects of Pycnogenol ${ }^{\circledR}$ on PC12 cells, describing the prevention of $A \beta_{25-35}$-induced losses of cell viability after pre-treatment with Pycnogenol ${ }^{\circledR}$ in concentrations of $20-60 \mu \mathrm{g} / \mathrm{ml}$. Furthermore, they have described a significantly decreased number of apoptotic cells after pre-treatment with Pycnogenol $^{\circledR}$ in concentrations of $10-60 \mu \mathrm{g} / \mathrm{ml}$ Pycnogenol ${ }^{\circledR}$ as well as a dose-dependent reduction of caspase3 activity. The neuroprotective effects of Pycnogenol ${ }^{\circledR}$ against the cytotoxicity of ethanol in cerebral granule cells, including the reduction of reactive oxygen species' products and the effects on antioxidative enzyme activities, has been shown by Silar-Marsiglio et al. (2004) by using Pycnogenol ${ }^{\circledR}$ in a concentration of $50 \mu \mathrm{g} / \mathrm{ml}$.

Used in concentrations ranging from 20 to $100 \mu \mathrm{g} / \mathrm{ml}$, neuroprotective effects of Pycnogenol $^{\circledR}$ could be observed, whereas no impacts on cell survival could be observed in this concentration range. On the other hand, our study has demonstrated that Pycnogenol ${ }^{\circledR}$ led to a significant enhancement of cell survival at lower concentrations $(31.25,125$ and 250 $\mathrm{ng} / \mathrm{ml})$

Our investigation of the plant extracts Pycnogenol ${ }^{\circledR}$ and Enzogenol ${ }^{\circledR}$ has shown no significant effects on energy metabolism when used in concentrations of 500 and $5000 \mathrm{ng} / \mathrm{ml}$. 
However, treatment with Hypericum perforatum extract in a concentration of $5000 \mathrm{ng} / \mathrm{ml}$ has induced a significant increase of ATP content in SH-SY5Y cells. This result has been in line with some other examinations (e. g. Breyer et al., 2007), describing that the extract has been able to counteract the glutamate induced energy loss, suggesting that Hypericum perforatum has antioxidative and neuroprotective properties. The concentrations of the drugs which we applied here ranging from 31.25 to $5000 \mathrm{ng} / \mathrm{ml}$ were derived from clinical studies. In clinical studies the concentrations of the drugs ranged from $1 \mathrm{mg} / \mathrm{kg} /$ day to $1 \mathrm{~g} / \mathrm{kg} / \mathrm{day}$.

In summary, the efficiency of plant extracts has been shown in clinical studies of patients with ADHD. Hence, plant extracts seem to be alternatives for patients who do not respond to the classical ADHD treatment with psychostimulants or atomoxetin. In order to identify the plant extracts' exact mechanism of action, further investigations on the components of oxidative stress and apototic parameters will be mandatory. There exists a theory on the mechanism of action of psychostimulants, stating that reduced dopamine contents in cells lead to decreased contents of both hydrogen peroxide and other products of oxidative stress, as a lowered number of dopamine is deaminated by monoaminooxidase. These parameters would be of particular interest in terms of possible relations to psychostimulants.

\section{Acknowledgement}

We thank Mrs. Sabine Fischer for the technical composition and realization as well as Mrs. Sibylle Tomakidi for the linguistic revision and refinement.

\section{Conflict of Interest}

Ulrich M. Hemmeter received grants from Böhringer and Lilly Schweiz. Eberhard Schulz received grants from Janssen-Cilag, Eli Lilly, Novartis, Shire and Pfizer. 
Philip Heiser received compensation for professional services from Janssen-Cilag, Shire and Novartis.

\section{References}

Ansari, M.A., Keller J.N., Scheff, S.W., 2008. Protective effect of Pycnogenol in human neuroblastoma SH-SY5Y cells following acrolein-induced cytotoxicity. Free Rad. Biol. Med. $45,1510-1519$.

Antalis, C.J., Stevens, L.J., Campbell, M., Pazdro, R., Ericson, K., Burgess, J.R., 2006. Omega-3 fatty acid status in attention-deficit/hyperactivity disorder. Prostaglandins Leukot. Essent. Fatty Acids 75, 299-308.

Benedi, J., Arroyo, R., Romero, C., Martin-Aragon, S., Villar, A.M., 2004. Antioxidant properties and protective effects of a standardized extract of Hypericum perforatum on hydrogen peroxide-induced oxidative damage in PC112 cells. Life Sci. 75, 1263-1276.

Berryman, A.M., Maritim, A.C., Sanders, R.A., Watkins, 3rd. J.B., 2004. Influence of treatment of diabetic rats with combinations Pycnogenol, beta-carotene and alpha-lipoic acid on parameters of oxidative stress. J. Biochem. Mol. Toxicol. 18, 345-352.

Breyer, A., Elstner, M., Gillessen, T., Weiser, D., Elstner E., 2007. Glutamate-induced cell death in neuronal HT22 cells is attenuated by extracts from St. John's wort (Hypericum perforatum L.). Phytomedicine 14, 250-255.

Bulut, M., Selek, S., Gergerlioglu, H.S., Savas, H.A., Yilmaz, H.R., Yuce, M., Ekici, G., 2007. Malondialdhyde levels in adult attention-deficit hyperactivity. J. Psychiatry Neurosi. $32,435-438$. 
Chovanova, Z.., Muchova, J., Sivonova, M., Dvorakova, M., Zittnanova, I., Waczulikova, I., Trebaticka, J., Skodacek, I., Durackova, Z., 2006. Effect of polyphenolic extract, Pycnogenol $^{\circledR}$, on the level 8-oxoguanine in children suffering from attention deficit/hyperactivity disorder. Free Rad. Res. 40, 1003-1010.

Elia, J., Ambrosini, P.J., Rapoport, J.L., 1999. Treatment of attention-deficit-hyperactivity disorder. N. Engl. J. Med. 340, 780-788.

El-Sherbiny, D.A., Khalifa, A.E., Attia, A.S., Eldenshary, E. E-D. S., 2003. Hypericum perforatum extract demonstrates antioxidant properties against elevated rat brain oxidative status induced by amnestic dose of scopolamine. Pharmacol. Biochem. Behav. 76, 525-533.

Fitzpatrick, D.F., Bing, B., Rohdewald, P., 1998. Endothelium-dependent vascular effects of Pycnogenol $^{\circledR}$. Free Rad. Res. 32, 509-515.

Joshi, K., Lad, S., Kale, M., Patwardhan, B., Mahadik, S.P., Patni, B., Chaudhary, A., Bhave, S., Pandit, A., 2006. Supplementation with flax oil and vitamin C improves the outcome of Attention Deficit Hyperactivity Disorder (ADHD). Prostaglandins Leukot. Essent. Fatty Acids 74, 17-21.

Kobayashi, M.S., Hans, D., Packer, L., 2000. Antioxidants and herbal extracts protects HT-4 neuronal cells against glutamate-induced cytotoxicity. Free Rad. Res. 32, 115-124.

Lyon, M.R., Cline, J.C., Totosy de Zepetnek, J., Shan, J.J., Pang, P., Benishin, C., 2001. Effect of the herbal extract combination Panax quinquefolium and Ginkgo biloba on attention-deficit hyperactivity disorder: a pilot study. J Psychiatry Neurosci 26, 221-228.

Niederhofer H., 2010. Ginkgo biloba treating patients with attention-deficit disorder. Phytother. Res. 24, 26-27. 
Packer, L., Rimbach, G., Virgili, F., 1999. Antioxidant activity and biologic properties of a procyanidin-rich extract from pine (Pinus maritima) bark, Pycnogenol ${ }^{\circledR}$. Free Rad. Biol. Med. 27, 704-724.

Peng, Q.L., Buz'Zard, A.R., Lau, B.H.S., 2002. Pycnogenol ${ }^{\circledR}$ protects neurons from amyloid $\beta$ peptide-induced apoptosis. Mol. Brain Res. 104, 55-65.

Pipingas, A., Silberstein, R.B., Vitetta, L., Van Rooy, C., Harris, E.V., Young, J.M., Frampton, C.M., Sali, A., Nastasi, J., 2008. Improved cognitive performance after dietary supplementation with a Pinus radiata bark extract formulation. Phytother. Res. 22, 1168-1174.

Ross, B.M., McKenzie, I., Glen, I., Bennett, C.P.W., 2003. Increased levels of ethane, a noninvasive marker of n-3 fatty acid oxidation, in breath of children with attention deficit hyperactivity disorder. Nutr. Neurosci. 6, 277-281.

Sanchez-Reus, M.I., Gomez del Rio, M.A., Iglesias, I., Elorza, M., Slowing, K., Benedi, J., 2007. Standardized Hypericum perforatum reduces oxidative stress and increase gene expression of antioxidant enzymes on rotenone-exposed rats. Neuropharmacology 52, 606616.

Salehi, B., Imani, R., Mohammadi, M.R., Fallah, J., Mohammadi, M., Ghanizadeh, A., Tasviechi, A.A., Vossoughi, A., Rezazadeh, S.A., Akhondzadeh, S., 2010. Ginkgo biloba for attention-deficit/hyperactivity disorder in children and adolescents: a double blind, randomized controlled trial. Prog. Neuropsychopharmacol. Biol. Psychiatry 34: 76-80.

Selek, S., Savas, H.A., Gergerlioglu, H.S., Bulut, M., Yilmaz, H.R., 2008. Oxidative imbalance in adult attention deficit/hyperactivity disorder. Biol. Psychol. 79, 256-259.

Siler-Marisiglio, K.J., Paiva, M., Madorsky, I., Serrano, Y., Neely, A., Heaton, M.B., 2004. Protective mechanisms of Pycnogenol in ethanol-insulted cerebellar granule cells. J. Neurobiol. 61, 267-276. 
Spahis, S., Vanasse, M., Belanger, S.A., Ghadirian, P., Grenier, E., Levy, E., 2008. Lipid profile, fatty acid composition and pro- and anti-oxidant status in pediatric patients with attention-deficit/hyperactivity disorder. Prostaglandins Leukot. Essent. Fatty Acids 79, 47-53.

Tenenbaum, S., Pauli, J.C., Sparrow, E.C., Dodd, D.K., Green, L., 2002. An experimental comparison of Pycnogenol ${ }^{\circledR}$ and methylphenidate in adults with attention-deficit/hyperactivity disorder (ADHD). J. Atten. Disord. 6, 49-60.

Trebaticka, J., Kopasova, S., Hradecna, Z., Cinovsky, K., Skodacek, I., Suba, J., Muchova, J., Zitnanova, I., Waczulikova, I., Rohdewald, P., Durackova, Z., 2006. Treatment of ADHD with French maritime pine bark extract, Pycnogenol ${ }^{\circledR}$. Eur. Child. Adolesc. Psychiatry 15, $329-335$.

Weber, W., Vander Stoep, A., McCarty, R.L., Weiss, N.S., Biederman, J., McClellan, J., 2008. Hypericum perforatum (St John's wort) for attention-deficit/hyperactivity .disorder in children and adolescents. JAMA 29, 2633-2641.

Young, J.M., Shand, B.I., McGregor, P.M., Scott, R.S., Rampton, C.M., 2006. Comparative effects of enzogenol and vitamin $\mathrm{C}$ supplementation versus vitamin $\mathrm{C}$ alone or endothelial function and biochemical markers of oxidative stress and inflammation in chronic smokers. Free Rad. Res. 40, 85-94. 


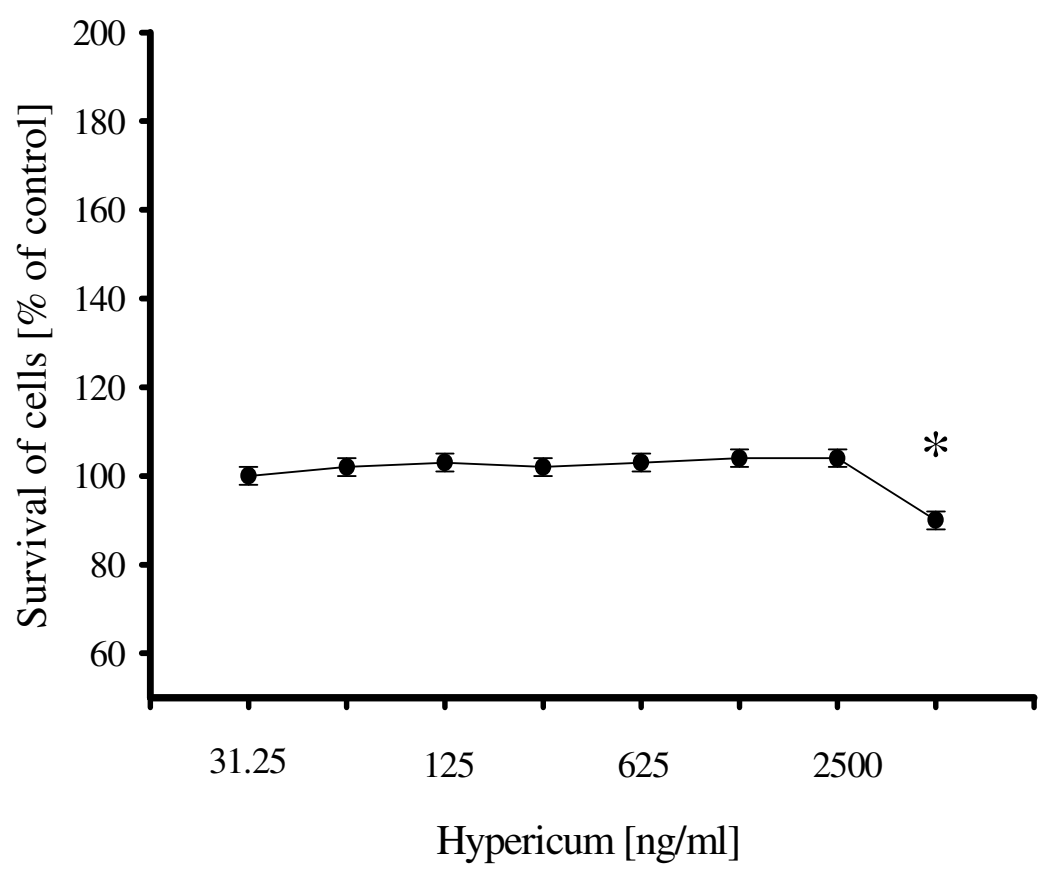

Figure1: Effects of Hypericum perforatum extract on cell survival of SH-SY5Y cells 




Figure 2: Effects of Pycnogenol ${ }^{\circledR}$ on cell survival of SH-SY5Y cells 


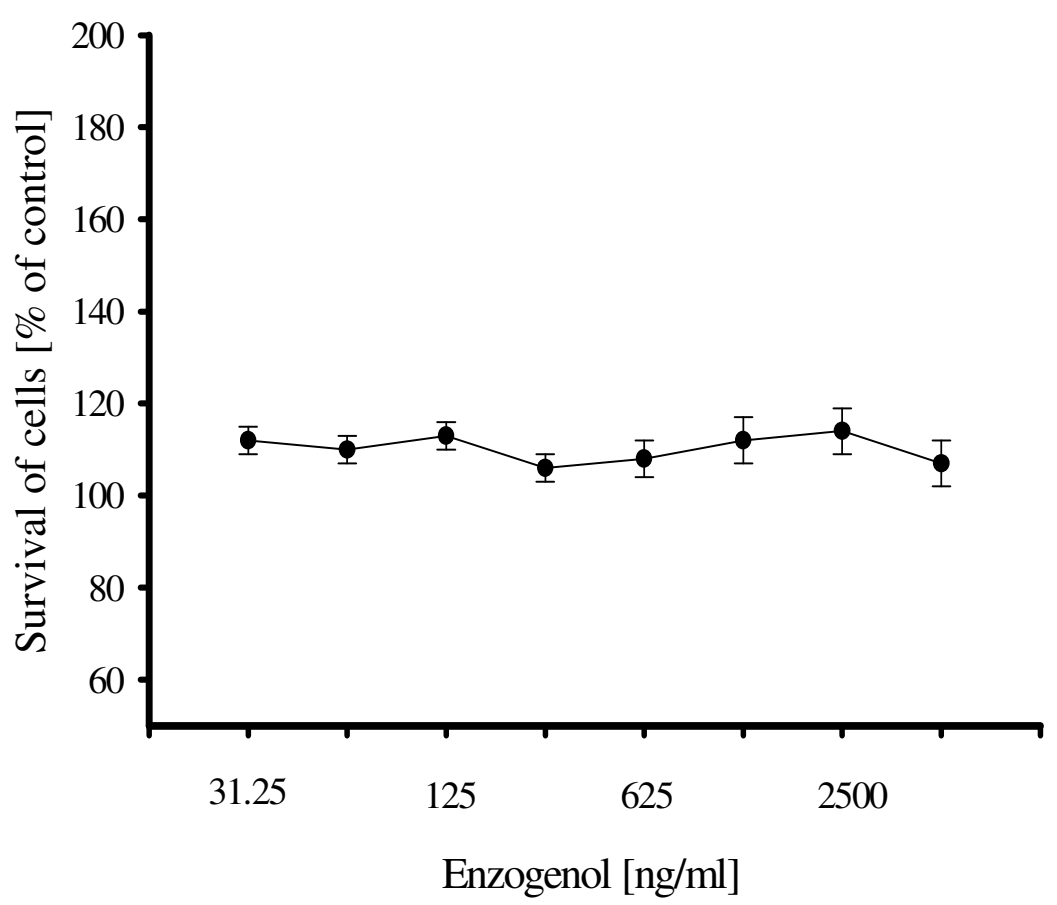

Figure 3: Effects of Enzogenol ${ }^{\circledR}$ on cell survival of SH-SY5Y cells 


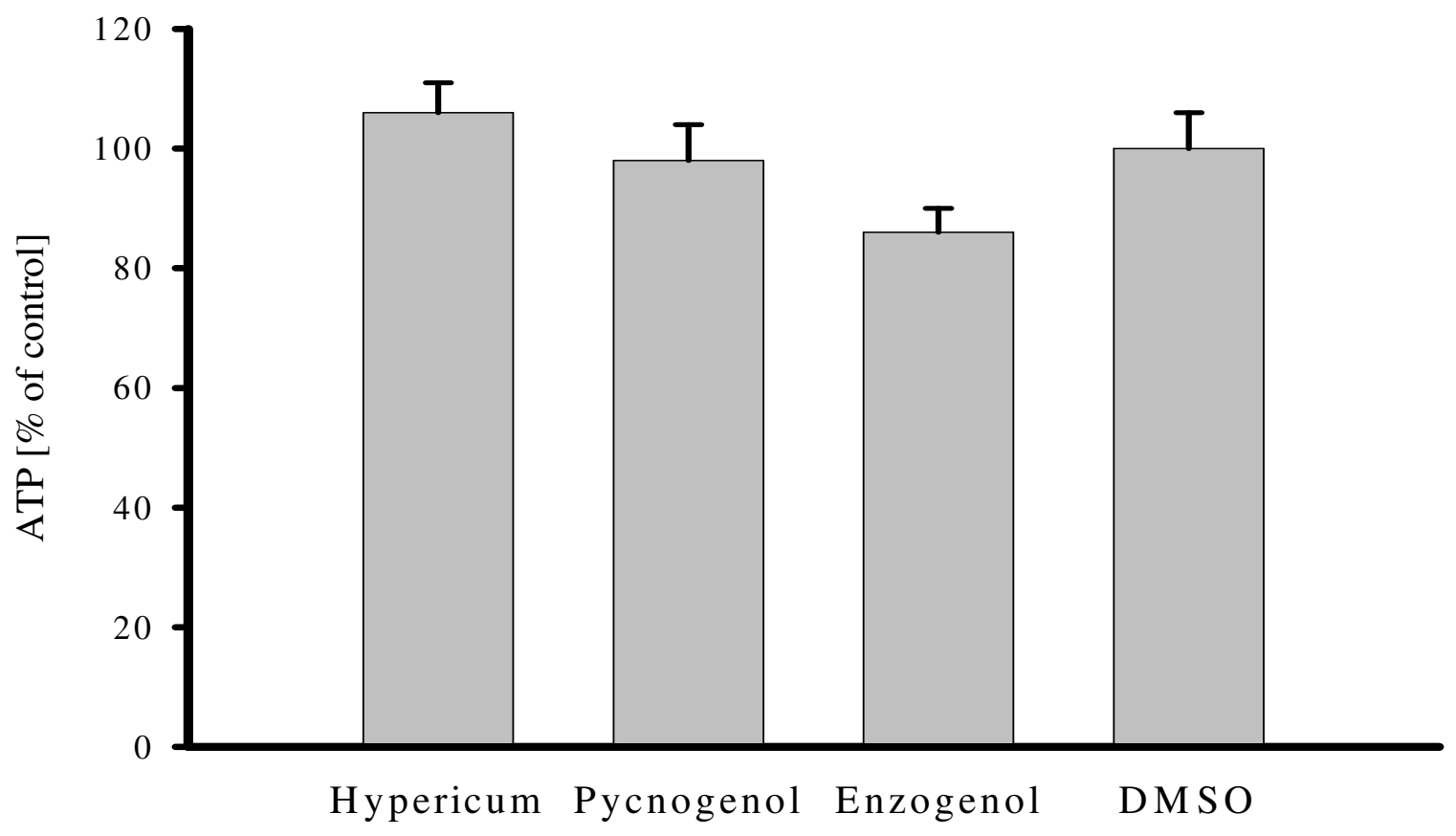

Figure 4: Effects of $500 \mathrm{ng} / \mathrm{ml}$ plant extract on ATP content of SH-SY5Y cells 
Schmidt et al.

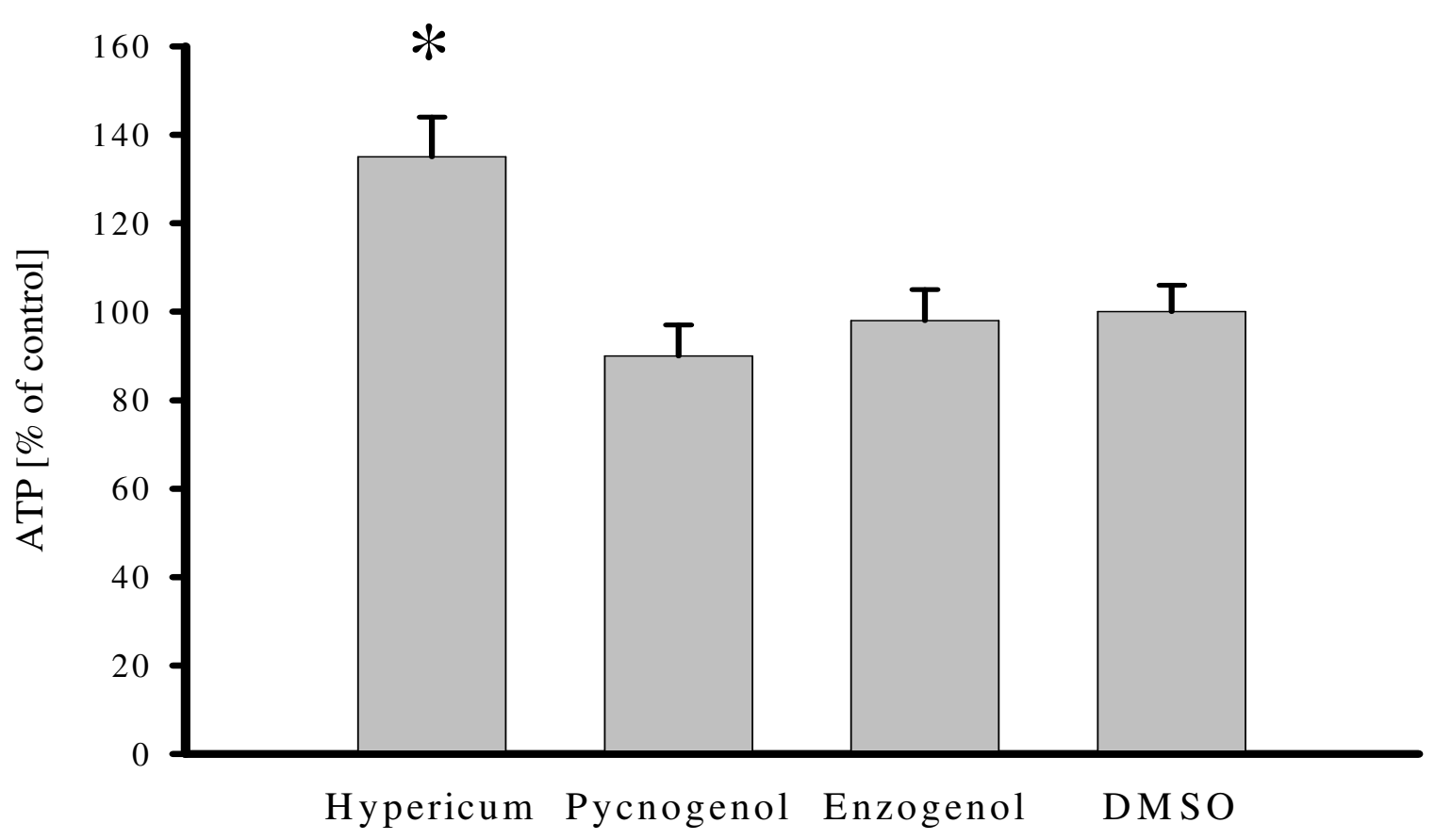

Figure 5: Effects of $5000 \mathrm{ng} / \mathrm{ml}$ plant extract on ATP content of SH-SY5Y cells 